\title{
Effective promotion of healthy nutrition and physical activity in Europe requires skilled and competent people; European Master's Programme in Public Health Nutrition*
}

\author{
Agneta Yngve ${ }^{1 * *}$, Michael Siöström ${ }^{1,2}$, Daniel Warm ${ }^{1,3}$, Barrie Margetts ${ }^{3}$, \\ Carmen Pérez Rodrigo ${ }^{4}$ and Aulikki Nissinen ${ }^{5}$ \\ 'Unit for Preventive Nutrition, Department of Biosciences, Karolinska Institutet, 14157 Huddinge, Sweden: \\ ${ }^{2}$ Department of Physical Education and Health, University of Örebro, 70182 Örebro, Sweden: \\ ${ }^{3}$ Institue of Human Nutrition, University of Southampton, Southampton SO 16 6YD, UK: \\ ${ }^{4}$ Community Nutrition Unit, Department of Public Health, 48013 Bilbao, Spain: \\ ${ }^{5}$ Department of Community Health and General Practice, University of Kuopio, 70211 Kuopio, Finland
}

Accepted: 16 July 1999

\begin{abstract}
Scientists in basic research and epidemiology deliver messages to policy makers. Effective population based strategies then require people trained and competent in the discipline of Public Health Nutrition (PHN). Since 1997, a European Master's Programme in PHN has been undergoing planning and implementation with the aid of funding from the European Commission (DGV). PHN is used as a broad term covering Nutrition and Physical Activity as well as Health Promotion and Disease Prevention.

The partners in this project are academic departments from 17 countries. The students will undertake core modules and electives for a year and a half, followed by a research project for six months. In order to set up formalised procedures for the evaluation of the quality assurance of individual modules from across Europe, a quality assurance system has been set up.

The academic year 1999-2000 will allow an opportunity for Universities and Institutes to start new modules, to develop other modules, assess the movement of students between modules, tackle funding issues and allow further marketing of the programme. Future activities include strengthening of the European Network for Public Health Nutrition (ENPHN), the establishment of a consortium with universities, the co-ordination of programme activities with other European Master's Programmes in Public Health, and the incorporation of new Member States from Eastern Europe.

We can look forward to a new brand of professionals, who are truly European in their training, but who also have an integrated view of nutrition and physical activity, health promotion and disease prevention and who are prepared for policy making, action planning, implementation and evaluation.
\end{abstract}

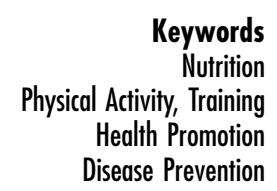

\section{Introduction}

There is a need for further research on interactions and potential synergy between diet and physical activity as an effective means for the promotion of a healthier life-style and the prevention of hypertension, obesity, cardiovascular disease and cancer. Good scientific evidence is the base for clear messages to the public. The task of developing and undertaking effective population-based strategies over Europe demands people that are trained and competent with comparable skills. This calls for proper training across Europe.

\footnotetext{
*The authors are all members of the Executive Committee for the
} Project.
With the aid of funding from Directorate General V (DGV) of the European Commission, (i.e. the Directorate covering Public Health 1996-2000), the Karolinska Institutet, Stockholm, has been asked to act as their representative in the setting up of a panEuropean Master's programme in Public Health Nutrition. The project involves all the European Union member states (except Luxembourg) as well as Iceland, Norway and Switzerland, a total of 17 countries (Table 1). It was introduced with the view to increasing the European dimension, improving the quality of existing training programmes in Public Health, and introducing a new area of specialisation within public health. 
Table 1 Country representatives in the Working Group/Network responsible for the development of the European Master's Programme in Public Health Nutrition

\begin{tabular}{|c|c|c|}
\hline & Institution & Contact person \\
\hline $\bar{A}$ & $\begin{array}{l}\text { Univ Vienna } \\
\text { Inst f Ernährungswissenschaften }\end{array}$ & I Elmadfa \\
\hline$B$ & $\begin{array}{l}\text { Univ Gent } \\
\text { Dept Public Health \& } \\
\text { Dept Food Technol Nutrition }\end{array}$ & AM Remaut de Winter \\
\hline $\mathrm{D}$ & $\begin{array}{l}\text { University of Giessen } \\
\text { Dept Nutr Sci }\end{array}$ & M Burkard \\
\hline DK & $\begin{array}{l}\text { Royal Vetr Agric Univ, Copenhagen } \\
\text { Res Dept Human Nutrition }\end{array}$ & J Haraldsdottir \\
\hline E & $\begin{array}{l}\text { Univ Navarra } \\
\text { Dept Publ Health, Dietetics }\end{array}$ & $\mathrm{J}$ Aranceta \\
\hline $\mathrm{F}$ & $\begin{array}{l}\text { Univ Victor Segalen, Bordeaux } 2 \\
\text { Inst Santé Publ \& Develop }\end{array}$ & D Malvy \\
\hline $\mathrm{FI}$ & $\begin{array}{l}\text { Univ Kuopio } \\
\text { Dept Public Health Gen Practice }\end{array}$ & A Nissinen \\
\hline $\mathrm{G}$ & $\begin{array}{l}\text { Nat School Publ Health, Athens } \\
\text { Dept Nutr Biochemistry }\end{array}$ & A Trichopoulou \\
\hline IL & $\begin{array}{l}\text { Univ Iceland, Reykjavik } \\
\text { Dept Food Science }\end{array}$ & I Thorsdottir \\
\hline I & $\begin{array}{l}\text { Nat Inst Nutrition, Rome } \\
\text { Unit Human Nutr }\end{array}$ & A Ferro-Luzzi \\
\hline IR & $\begin{array}{l}\text { Trinity Coll Med School } \\
\text { Dept Clin Med }\end{array}$ & M Gibney \\
\hline $\mathrm{N}$ & $\begin{array}{l}\text { Univ Oslo } \\
\text { Inst Nutrition Research }\end{array}$ & KI Klepp \\
\hline NL & $\begin{array}{l}\text { Wageningen Agric Univ } \\
\text { Dept Human Nutrition }\end{array}$ & Joop van Raaij \\
\hline$P$ & $\begin{array}{l}\text { Porto Univ } \\
\text { Curso de Ciencias Nutricao \& } \\
\text { Human Nutr }\end{array}$ & M D Vaz de Almeida \\
\hline$S$ & $\begin{array}{l}\text { Karolinska Institutet, Stockholm } \\
\text { Dept Med Nutr \& Dept Biosci }\end{array}$ & $\begin{array}{l}\text { A Yngve, } \\
\text { M Sjöström }\end{array}$ \\
\hline $\mathrm{CH}$ & $\begin{array}{l}\text { Univ Zürich } \\
\text { Inst Soc Prev Med }\end{array}$ & F Gutzwiller \\
\hline UK & $\begin{array}{l}\text { Queen Margaret Univ Coll } \\
\text { Edinburgh }\end{array}$ & $\mathrm{J}$ Landman \\
\hline UK & $\begin{array}{l}\text { Univ Southampton } \\
\text { Inst Human Nutr }\end{array}$ & $\begin{array}{l}\text { B Margetts, } \\
\text { D Warm }\end{array}$ \\
\hline
\end{tabular}

\section{Community Action in Public Health}

Public Health has become a particular focus of the Commissions' work since it set out its framework for action in the field in 1993. This framework for action was to be used as the basis for Article 129 of the EC's Maastricht Treaty. The Article's main provisions include:

- the community shall contribute towards ensuring a high level of human health protection by encouraging co-operation between the member states,

- community action on health promotion should be focused on the prevention of diseases,
- community activities in the field of public health should concentrate particularly on the major health 'scourges'.

Since the signing of the Maastricht Treaty the Commission has further developed its position with regard to Public Health, which includes Public Health Nutrition (see below). The Amsterdam Treaty of 1998 will now supersede the Maastricht Treaty, with public health remaining a priority (Article 152 in the new treaty).

With this in mind, DG V, through its Health Promotion Unit, $\mathrm{F} / 3$, is at present funding projects looking at the setting up of a number of pan European Master's programmes. Apart from the programme in Public Health Nutrition, it is initially the intention to have Masters programmes in Public Health, Health Promotion and Gerontology (1999 Work programme of the Community Action Programme on Health Promotion, Information, Education and Training).

\section{Public Health Nutrition, a definition}

'Public Health Nutrition focuses on the promotion of good health through nutrition and physical activity and the prevention of related illness in the population' (The Working Group for the European Master's Programme for Public Health Nutrition, 1998, adapted from the Nutrition Society's definition 1997).

Nutrition and physical activity are separated by tradition in the academic structure, but they are inevitably linked in the public health context, in health care and in daily life. For example, the time spent being physically active, as well as the intensity of the activity, seem to have an impact on appetite, energy needs, food choice and meal patterns. In contrast, the food choice, meal patterns and energy intake influence physical activity level and patterns. The influence of both nutrition and physical activity, either separately or combined, on the development of overweight, diabetes, heart disease and some forms of cancer are other examples. Patterns of low physical activity coincide with poorer or less healthy eating patterns and other risk behaviours, especially in less educated groups. The health gap between socio-economic groups is increasing all over Europe.

\section{The European Master's Programme for PHN}

A Working Group was formed in 1997, containing expertise in PHN from all the countries involved. This work has been led by an Executive Committee, COordinated by the Unit for Preventive Nutrition at Karolinska Institutet, Stockholm. The work has built 
on what has been accomplished by a PHN development group within The Nutrition Society (UK).

The main aim of the project is the setting up of a pan European Master's programme in PHN. The field of PHN is becoming prominent as the move continues towards promoting health at a population level rather than at an individual level. The long-term goal of the Master's-project must be seen as contributing to the improvement in the health of people across Europe. The task of undertaking effective population-based strategies over Europe in the field of PHN demands people that are trained and competent, with comparable skills.

These individuals must be able to:

- apply knowledge, leading to research led action,

- use evidence based practice, evaluation and monitoring,

- link policy to evidence (i.e. feedback).

This calls for proper training across Europe, leading to the development of comparably skilled and competent individuals. In order to achieve this, common standards of training should be set and monitored. At a European level, in the long term this will lead to the following.

- The creation of partnerships between training institutions in PHN within the EU.

- The development of cost-effective intervention programmes for use across Europe.

- The development of an awareness of the European perspective, and of EU policies \& actions.

- Contributing to the development of a European concept in the health sector in the Member States.

- An increase in the number of decision-makers, as well as trainers, with a knowledge of PHN within the EU.

- Preparation of future PHN professionals for the European market.

\section{Admission and level}

Students must fulfil an admissions criterion for entry to the course. This should consist of at least two years of academic training, including either basic physiology, nutrition or public health. Within the programme, they will undertake the equivalent of 90 ECTS (1.5 ECTS is approximately one week of full time study; ECTS = European Credit Transfer System) of core modules and electives (Table 2), followed by a research project (and thesis) worth 30 ECTS (Fig. 1).

As the course is at Master's level, the students must undertake learning that is complex, unpredictable and, normally, including specialised situations demanding innovative work, which may involve exploring the current limits of knowledge.

For each of the specified core modules, specialist
Table 2 List of core modules to be included in the European Master's Programme in Public Health Nutrition and number of European Credit Transfer System (ECTS) assigned to each (1.5 ECTS corresponds to one week of full-time study)

- The principles of nutritional science 5 ECTS

- The principles of public health 10

- The principles of physical activity

5

- The principles of health promotion

- Epidemiology and biostatistics

- Assessment methods in nutrition and physical activity

- EU Basics in public health nutrition

- Food habits: An integrated perspective

- Food and nutrition policy

- Food safety

- Electives**

10

10

10

5

10

5

3 to 30

${ }^{* *}$ Electives are for example: Nutrition and Physical Activity interventions in schools, Courses on Biomarkers, Nutrition and Physical Activity for Elderly, Physical activity interventions in primary health care.

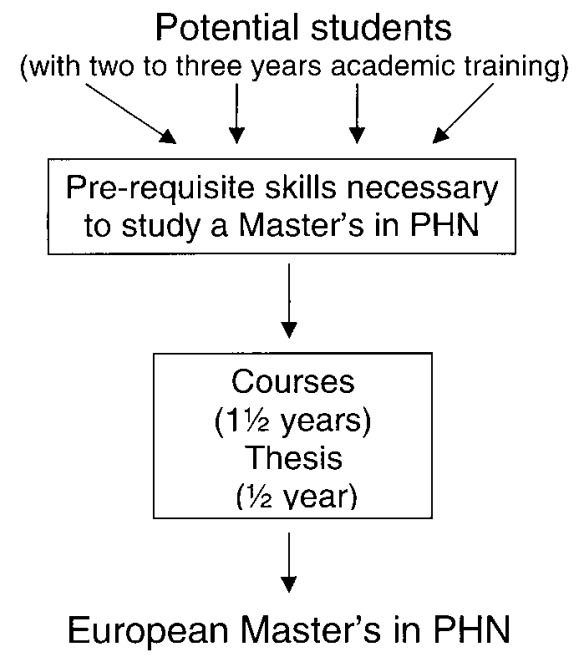

Fig. 1 Schematic drawing of the Master's programme

groups were set up to design the curriculum, according to the descriptors listed in Table 3. This process is on going to ensure that each module is as complete as possible and that the course literature and other materials are kept up to date. Additionally, this allows the modules to be developed in such a way that these are at the required high level (i.e. Master's level), but also make them coherent and will allow students to

Table 3 Module descriptors
- Number of ECTS
- Prerequisite modules
- Aim
- Objectives
- Course content
- European dimension
- Physical activity dimension
- Teaching and learning approaches
- Assessment of module
- Indicative reading, learning resources

- Examination procedures 
pass between modules as easily as possible. The modules will also in many cases be possible to study as separate items.

In addition it was agreed that the programme should include a research project and thesis. The research must demonstrate the integration of concepts across modules in the way the project is undertaken and discussed. This would include study design etc., but must also show that the student has been able to consider the wider Public Health context (the European dimension) of the work undertaken.

\section{Quality Assurance}

Much time and effort has been spent exploring and assessing the issue of the quality of the programme. There must be an open, transparent and equitable system that ensures comparability of courses across Europe. In order to set up formalised procedures for the quality assurance of individual modules from across Europe, a quality assurance system, that includes a quality committee, has been set up. With a practical and workable package, it will be possible to determine the efficacy of the modules being offered and thus will support the principle set up, for assuring the standards of the students leaving our programme.

\section{Year 2000}

The academic year 1999-2000 will act as a developmental year for the programme. This year will allow an opportunity for Universities and Institutes to start new modules, allow the development of other modules, assess and facilitate the movement of students between modules and teachers between universities, tackle funding issues and allow further marketing of the programme. In addition, to the tasks specified, it is the intention to further advance the programme by:

- strengthening the European Network for Public Health Nutrition,
- establishing a University consortium between the participating centres,

- further integrating and co-ordinating the tasks of this programme along with that of the Master's programme in Health Promotion, particularly with regard to the module 'EU Basics',

- further developing mobility for students and staff,

- introducing representatives from the new member states of Eastern Europe,

- developing distance learning/training packages for selected modules.

\section{Bottom line}

Through the support that the European Commission is giving to postgraduate training in PHN across Europe, we can hope for increased mobility, networking and understanding between European nutrition and physical activity professionals. We can look forward to a new brand of professionals, who are truly European in their training, but who also have an integrated view of nutrition AND physical activity, interrelations, possibilities for intervention etc. We have never before had so great a possibility for developing the field of public health nutrition. With those possibilities follow increased demands for showing cost efficiency and positive results. This can only be reached through increased specialisation, hard work and collaboration with other professionals over borders and within countries.

\section{Acknowledgements}

This project has been funded from Directorate General $\mathrm{V}(\mathrm{DGV} / \mathrm{F} / 3)$ of the European Commission. The Working Group would like to thank Dr Matti Rajala and co-workers, especially Dr Henriette Chamouillet, for continuous support and stimulating exchange of ideas and experiences. The expert advice given by Dr Jacqueline Landman, Queen Margaret University College, Edinburgh, has been greatly appreciated. 